\title{
AN ANALYSIS OF SECONDARY SCHOOL STUDENTS' VALUES REGARDING PHYSICAL EDUCATION AND SPORTS LESSONS
}

\author{
Serdar Özçetin, \\ Mert Kurnaz, \\ Mustafa Altınkök ${ }^{i}$ \\ Akdeniz University, \\ Faculty of Sport Sciences, \\ Department of Physical Education and Sports, \\ Antalya, Turkey
}

\begin{abstract}
:
This research aims to determine the basic value levels of students for physical education and sports lessons and to examine them according to various variables. The research has been designed as a descriptive survey model. The universe of the research consists of the students studying at a Secondary School affiliated to the Istanbul Provincial Directorate of National Education. The sample group consists of a total of 908 students studying in Istanbul in the 2020-2021 academic year, who were determined by the purposeful sampling method. The "Physical Education and Sports Lesson Value Scale (PESLVS)" was used as the data collection tool. The data collection tool is a 5-point Likert-type scale consisting of 23 items and 6 subdimensions. The Cronbach alpha reliability coefficient of the scale obtained in this research was 0.84 . Frequency, percentage, t-test for unrelated samples, and ANOVA were used in the analysis of the data. When the value levels of the students were examined, it was found that there was a significant difference in favor of female students in all dimensions. It was observed that the value levels of secondary school students differed significantly in all dimensions of the scale by grade level, and it was concluded as a result of the comparison between the groups that there was a significant difference in favor of the lower grade levels in all groups. It was concluded that the value levels of the students who played in the school team was higher.
\end{abstract}

Keywords: values, values education, sport and value, physical education and sports

\section{Introduction}

Values, one of the most important matters for people, society and nations, can raise humanity and nations to the highest level. People express the state of affairs they desire, believe and use as a scale for their behavior, with values. It was Znaniecki who first

i Correspondence: email mustafaaltinkok@akdeniz.edu.tr 
introduced the concept of values to social sciences. It is a concept derived from the root "valere" in Latin, which means "to be strong" or "to be valuable" (Bilgin, 1995). Any inconsistency in values inevitably leads to an imbalance in human life, and values determine the consistency, goals, ideals and stability of society. Values regulate people and serve as the foundation of relationships and social life (Perry, 1988). For this reason, societies strive to raise their future generations and make these principles a viable choice depending on the system of principles they believe in (Al-Serhan, 2015).

In the world we live in, the fact that concepts such as honesty, respect, moral values, establishing communication, caring for human relations, obeying the rules of courtesy, business discipline, cleanliness, order, which have become indispensable for modern life, come to the fore as much as academic success reveals the necessity of values education in schools (Aydin and Akyol, 2012). As it is known, one of the purposes of education is to transfer the value judgments of the society to the next generation. This transfer is carried out openly or implicitly through the management processes in schools. Here again, effective leadership of educators and education managers play an important role in the preparation of programs and in transferring these values (Akbaba-Altun, 2003). It is also stated that the qualities that instill children to be good people and that they need to be in order to become respected members of the society with basic root values, can be provided by physical education and sports activities (Dunn, Kinney and Hofferth, 2003). It is stated in the curriculum of the physical education and sports education course that physical education and sports activities, which are accepted as an activity area where students make sports a lifestyle and aim the development of students physically and mentally from the past to the present and to the future, are the values that skills, knowledge, attitudes and basic values should be transferred and be gained by students through these activities (Sağın and Karabulut, 2019).

The values that constitute the whole of the principles that form the perspective of the curriculum are expressed in the program as, "they are rooted in our traditions and the past, their bodies and branches are fed from these roots and extend to our present and tomorrow" (MEB, 2018). Moving from this point, the interest in the development of values has made it a core field in the field of education. The development and mechanisms of values are considered to be one of the supporting factors of national security in a holistic sense (Makroum, 2004). According to article 2 of the Basic Law of National Education, one of the general objectives of the law is "to raise individuals with a personality and character developed in a balanced and healthy way in terms of body, mind, morality, spirit, emotion, with free and scientific thinking, with a broad worldview, who are respectful of human rights, give importance to personality and effort, who have a responsibility towards society, and who are constructive, creative and productive" (Basic Law of National Education, 1973), which emphasizes the importance of values and values education. It is seen that values are included in all of the curriculums published by the Board of Education and the values that directly contribute to the establishment of social peace and socialization of people are included in the curricula. In this context, efforts are made for students to adopt basic root values such as friendship, giving importance to family integrity, peace, 
independence, justice, freedom, self-control, scientificity, diligence, solidarity, sensitivity, aesthetics, tolerance, hospitality, giving importance to being healthy, respect, love, responsibility, cleanliness, patriotism and benevolence (Yücekaya, 2017).

Yücekaya (2017) created the values scales for the courses applied by the Ministry of National Education in schools and a 6-dimensional values classification with an extensive literature review. The explanations for this classification are as follows: "Respect; shows that the student acknowledges and respects the presence of his/her opponent, teammate, and supporters in the physical education class. Awareness: expresses the awareness of the student's careful use of sports equipment and the awareness of not harming nature and the environment in sports activities. National Culture and Unity; refers to the student's adoption of National Culture such as supporting the National Sports Teams of our country and active participation in the National Day celebrations. Healthy Life and Nutrition; expresses the importance that students attach to physical education and sports activities, the contribution of sports to a healthy life, and a healthy diet. Solidarity; is related to students' fulfilling the duties in physical education and sports activities, supporting their teammates, attaching importance to team spirit, and establishing good communication with their friends. Sports Culture; represents students' attaching importance to wearing sportswear in physical education and sports activities, empathizing, being able to control themselves, fair play, enjoying the sports activities and excelling in them."

This research has its source in the vitality of the subject and the goals it is trying to reach. Since values play an important role in controlling and guiding human behavior, this research is important in that it examines and reveals students' commitment to basic root values. Accordingly, this study aims to determine the level of values of students for physical education and sports lessons and to examine them by several variables (gender, grade, and the status of playing in the school team).

\section{Method}

In this study, which examines the values of secondary school students for physical education and sports lessons, the screening model, which is a quantitative research approach, was adopted because of a past or currently existing situation (Karasar, 2005).

\subsection{Study Population and Sample}

The research population consists of 1,761 students studying at a Secondary School affiliated with the Istanbul Provincial Directorate of National Education. The sample group consists of a total of 908 students who were studying at the school in the 2020-2021 academic year, who were determined by the simple random (probability) sampling method, in which sampling units are selected randomly (Büyüköztürk et al., 2010). Information about the general characteristics of the sample group is given in Table 1. 


\begin{tabular}{llrl}
\hline \multicolumn{4}{c}{ Table 1: General characteristics of the students participating in the study } \\
\hline Variable & Variable Parameter & $\mathbf{N}$ & $\mathbf{\%}$ \\
\hline \multirow{2}{*}{ Gender } & Female & 525 & 57.8 \\
\cline { 2 - 5 } & Male & 383 & 42.2 \\
\hline \multirow{3}{*}{ Grade } & 5th Grade & 250 & 27.5 \\
\cline { 2 - 5 } & 6th Grade & 250 & 27.5 \\
\cline { 2 - 5 } & 7th Grade & 158 & 17.4 \\
\cline { 2 - 5 } Playing in the School Team & 8th Grade & 250 & 27.5 \\
\hline
\end{tabular}

When Table 1 is examined, it is seen that, of a total of 908 secondary school students participating in the study, $525(57.8 \%)$ are female, $383(42.2 \%)$ are male, $250(27.5 \%)$ are $5^{\text {th }}$ graders, $250(27.5 \%)$ are $6^{\text {th }}$ graders, $250(27.5 \%)$ are $8^{\text {th }}$ graders and $158(17.4 \%)$ are $7^{\text {th }}$ graders. It is observed that 138 of the participants (15.2\%) played in the school team, while $770(84.8 \%)$ did not play in the school team.

\subsection{Data Collection Tools}

A questionnaire form consisting of two parts was used as the data collection tool. The first part consists of the "demographic information form" with 10 questions containing the personal information of the students, and the second part consists of the "Physical Education and Sports Lesson Value Scale (PESLVS)". The data collection tool is a 5-point (Always, Often, Sometimes, Rarely and Never) Likert-type scale consisting of 23 items under 6 sub-dimensions [Factor 1: Respect (3 items), Factor 2: Awareness (2 items), Factor 3: National Culture and Solidarity (2 items), Factor 4: Healthy Living and Nutrition (3 items), Factor 5: Solidarity (5 items) and Factor 6: Sports Culture (8 items)]. The Cronbach's alpha reliability coefficient for the whole scale was $0.84,0.64$ for factor $1,0.56$ for factor 2, 0.47 for factor 3, 0.64 for factor 4, 0.75 for factor 5, and 0.74 for factor 6 .

\subsection{Data Analysis}

The data were analyzed and interpreted in a statistical analysis program (SPSS 22) and incomplete or incorrectly-filled questionnaire forms were excluded from the study. The scale was determined to be suitable for analysis after carrying out reliability studies. The Levene test, testing normality, was carried out to decide which analyzes to be made, and the test result revealed that all factors were suitable for normal distribution $(p>0.05)$. Since the data showed normal distribution, it was decided to perform parametric analyses. The arithmetic means and standard deviation values were examined in determining the values levels of students for the physical education and sports lesson. Frequency, percentage, t-test for unrelated samples, and one-way analysis of variance (ANOVA) were used in the analysis of the data. 


\section{Results}

This section contains findings and comments obtained in line with the objectives and subobjectives of the research. Table 2 shows the descriptive statistics on the dimensions of students' perceptions of values.

Table 2: The arithmetic means, standard deviation values of the students

\begin{tabular}{lcc}
\hline Dimensions & $\overline{\mathrm{X}}$ & $\mathrm{S}$ \\
\hline Sports Culture & 4.021 & 0.647 \\
\hline Healthy Life and Nutrition & 4.164 & 0.734 \\
\hline Solidarity & 4.435 & 0.636 \\
\hline Respect & 4.490 & 0.723 \\
\hline National Culture and Unity & 3.930 & 1.009 \\
\hline Awareness & 4.571 & 0.730 \\
\hline Total & 4.231 & 0.558 \\
\hline
\end{tabular}

When the arithmetic means and standard deviation values of the students participating in the study are examined in Table 2 , the respect $(\bar{X}=4,490, S=0.723)$ dimension is seen to be at the highest level. This dimension is followed by awareness ( $\bar{X}=4.571, S=0.730)$, solidarity $(\bar{X}=4.435, S=0.636)$, healthy life and nutrition $(\bar{X}=4.164, S=0.734)$, sports culture $(\bar{X}=4.021, S=0.647)$, and national culture and solidarity $(\bar{X}=3.930, S=1.009)$. When looking at the means of the items in the whole scale $(\bar{X}=4.231 \mathrm{~S}=0.558)$, it is seen that the value perceptions of the students are high.

The results of the T-test for independent samples made to compare the value levels related to the Physical Education course by the gender variable are given in Table 3.

Table 3: Comparison of value levels by the gender variable

\begin{tabular}{|c|c|c|c|c|c|c|c|}
\hline Dimension & Gender & $\mathbf{n}$ & $\overline{\mathrm{X}}$ & $S$ & $\mathbf{t}$ & SD & $\mathrm{p}$ \\
\hline \multirow{2}{*}{ Sports Culture } & Female & 525 & 4.12 & 0.583 & \multirow{2}{*}{5.57} & \multirow{2}{*}{0.906} & \multirow{2}{*}{0.000} \\
\hline & Male & 383 & 3.88 & 0.704 & & & \\
\hline \multirow{2}{*}{ Solidarity } & Female & 525 & 4.55 & 0.520 & \multirow{2}{*}{7.00} & \multirow{2}{*}{0.906} & \multirow{2}{*}{0.000} \\
\hline & Male & 383 & 4.26 & 0.735 & & & \\
\hline \multirow{2}{*}{ Healthy Life and Nutrition } & Female & 525 & 4.28 & 0.594 & \multirow{2}{*}{5.72} & \multirow{2}{*}{0.906} & \multirow{2}{*}{0.000} \\
\hline & Male & 383 & 4.00 & 0.866 & & & \\
\hline \multirow{2}{*}{ National Culture and Unity } & Female & 525 & 4.16 & 0.864 & \multirow{2}{*}{8.48} & \multirow{2}{*}{0.906} & \multirow{2}{*}{0.000} \\
\hline & Male & 383 & 3.60 & 1.102 & & & \\
\hline \multirow{2}{*}{ Awareness } & Female & 525 & 4.74 & 0.509 & \multirow{2}{*}{8.47} & \multirow{2}{*}{0.906} & \multirow{2}{*}{0.000} \\
\hline & Male & 383 & 4.33 & 0.904 & & & \\
\hline \multirow{2}{*}{ Respect } & Female & 525 & 4.63 & 0.572 & \multirow{2}{*}{7.32} & \multirow{2}{*}{0.906} & \multirow{2}{*}{0.000} \\
\hline & Male & 383 & 4.29 & 0.851 & & & \\
\hline \multirow{2}{*}{ Average } & Female & 525 & 4.36 & 0.438 & \multirow{2}{*}{8.61} & \multirow{2}{*}{0.906} & \multirow{2}{*}{0.000} \\
\hline & Male & 383 & 4.05 & 0.647 & & & \\
\hline
\end{tabular}

As seen in Table 3, there is a statistically significant difference in all dimensions in the results of the T-test for independent samples conducted to reveal whether there is a 
significant difference between the dimensions of the scale by gender of secondary school students participating in the study. In sports culture dimension $[t(906)=5.57 ; p<.01]$ it is seen that female students ( $\bar{X}=4.12, N=0.583$ ) have more positive views than male students $(\bar{X}=3.88, N=0.704)$. In the solidarity dimension $[t(906)=7.00 ; p<0.01]$ it is seen that female students $(\bar{X}=4.55, N=0.520)$ have more positive views than male students $(\bar{X}=4.26$, $\mathrm{N}=0.735)$. In the dimension of healthy life and nutrition [ $t(906)=5.72 ; \mathrm{p}<0.01]$ it is seen that female students $(\bar{X}=4.28, N=0.594)$ have more positive views than male students $(\bar{X}=4.00$, $\mathrm{S}=0.866)$. In the national culture and unity dimension $[\mathrm{t}(906)=8,48 ; \mathrm{p}<0.01]$ it is seen that female students $(\bar{X}=4.16, N=0.864)$ have more positive views than male students $(\bar{X}=3.66$, $\mathrm{S}=1.102)$. In the respect dimension $[\mathrm{t}(906)=7.32 ; \mathrm{p}<0.01]$ it is seen that female students $(\bar{X}$ $=4.63, \mathrm{~N}=0.572$ ) have more positive views than male students ( $\bar{X}=4.29, S=0.851)$. In terms of the averages $[t(906)=8.61 ; p<0.01]$, it is seen that female students $(\bar{X}=4.36, N=0.438)$ have more positive views than male students $(\bar{X}=4.05, S=0.647)$.

Table 4: Comparison of value levels by the grade

\begin{tabular}{|c|c|c|c|c|c|c|c|c|}
\hline Dimension & Grade & $\mathbf{n}$ & $\bar{x}$ & $\mathbf{S}$ & sd & $\mathbf{F}$ & $\mathbf{p}$ & $\begin{array}{c}\text { Significant } \\
\text { Difference } \\
\text { (Scheffe) }\end{array}$ \\
\hline \multirow{4}{*}{ Sports Culture } & A. 5th grade & 250 & 4.15 & 0.59 & \multirow{4}{*}{$3-904$} & \multirow{4}{*}{14.69} & \multirow{4}{*}{0.000} & \multirow{4}{*}{$\begin{array}{l}\text { A-D } \\
\text { B-D } \\
\text { C-D }\end{array}$} \\
\hline & B. 6th grade & 250 & 4.09 & 0.62 & & & & \\
\hline & C. 7 th grade & 158 & 4.03 & 0.56 & & & & \\
\hline & D. 8th grade & 250 & 3.80 & 0.70 & & & & \\
\hline \multirow{4}{*}{ Solidarity } & A. 5th grade & 250 & 4.53 & 0.56 & \multirow{4}{*}{$3-904$} & \multirow{4}{*}{12.24} & \multirow{4}{*}{0.000} & \multirow{4}{*}{$\begin{array}{l}\text { A-D } \\
\text { B-D } \\
\text { C-D }\end{array}$} \\
\hline & B. 6th grade & 250 & 4.53 & 0.65 & & & & \\
\hline & C. 7 th grade & 158 & 4.42 & 0.54 & & & & \\
\hline & D. 8th grade & 250 & 4.24 & 0.69 & & & & \\
\hline \multirow{4}{*}{$\begin{array}{l}\text { Healthy Life and } \\
\text { Nutrition }\end{array}$} & A. 5th grade & 250 & 4.28 & 0.70 & \multirow{4}{*}{$3-904$} & \multirow{4}{*}{10.28} & \multirow{4}{*}{0.000} & \multirow{4}{*}{$\begin{array}{l}\text { A-D } \\
\text { B-D } \\
\text { C-D }\end{array}$} \\
\hline & B. 6th grade & 250 & 4.19 & 0.76 & & & & \\
\hline & C. 7 th grade & 158 & 4.26 & 0.56 & & & & \\
\hline & D. 8th grade & 250 & 3.95 & 0.78 & & & & \\
\hline \multirow{4}{*}{$\begin{array}{l}\text { National Culture } \\
\text { and Unity }\end{array}$} & A. 5th grade & 250 & 4.12 & 0.91 & \multirow{4}{*}{$3-904$} & \multirow{4}{*}{28.29} & \multirow{4}{*}{0.000} & \multirow{4}{*}{$\begin{array}{l}\text { A-D } \\
\text { B-D } \\
\text { C-D }\end{array}$} \\
\hline & B. 6th grade & 250 & 4.16 & 0.91 & & & & \\
\hline & C. 7 th grade & 158 & 3.99 & 0.91 & & & & \\
\hline & D. 8th grade & 250 & 3.46 & 1.08 & & & & \\
\hline \multirow{4}{*}{ Awareness } & A. 5th grade & 250 & 4.62 & 0.71 & \multirow{4}{*}{$3-904$} & \multirow{4}{*}{3.63} & \multirow{4}{*}{0.013} & \multirow{4}{*}{ A-D } \\
\hline & B. 6th grade & 250 & 4.61 & 0.75 & & & & \\
\hline & C. 7 th grade & 158 & 4.62 & 0.60 & & & & \\
\hline & D. 8th grade & 250 & 4.44 & 0.78 & & & & \\
\hline \multirow{4}{*}{ Respect } & A. 5th grade & 250 & 4.61 & 0.65 & \multirow{4}{*}{$3-904$} & \multirow{4}{*}{8.75} & \multirow{4}{*}{0.000} & \multirow{4}{*}{ A-D } \\
\hline & B. 6th grade & 250 & 4.56 & 0.70 & & & & \\
\hline & C. 7 th grade & 158 & 4.46 & 0.69 & & & & \\
\hline & D. 8th grade & 250 & 4.31 & 0.79 & & & & \\
\hline & A. 5th grade & 250 & 4.35 & 0.50 & & & & \\
\hline & B. 6th grade & 250 & 4.31 & 0.55 & & & & $\begin{array}{l}\text { A-D } \\
\text { B D }\end{array}$ \\
\hline Average & C. 7 th grade & 158 & 4.25 & 0.46 & 3-904 & 20.15 & 0.000 & B-D \\
\hline & D. 8th grade & 250 & 4.01 & 0.61 & & & & C-D \\
\hline
\end{tabular}

The results of the ANOVA analysis conducted to compare the values levels related to the Physical Education course by the grade variable are given in Table 4.

As seen in Table 4, there is a statistically significant difference in all dimensions according to the results of the ANOVA conducted to reveal whether there is a significant 
difference between the secondary school students participating in the study by the grade variable. In the sports culture dimension $[\mathrm{F}(3-904)=14.69 ; \mathrm{p}<0.01)$, it is seen that there is a significant difference in favor of $5^{\text {th }}$ graders $(\bar{X}=4.15, S=0.59)$, 6th graders $(\bar{X}=4.09, S=0.62)$ and $7^{\text {th }}$ graders $(\bar{X}=4.03, S=0.56)$, when compared to $8^{\text {th }}$ graders $(\bar{X}=3.80, S=0.70)$. In the solidarity dimension $[\mathrm{F}(3-904)=12,24 ; \mathrm{p}<0.01]$, it is seen that there is a significant difference in favor of $5^{\text {th }}$ graders $(\bar{X}=4.53, S=0.56), 6^{\text {th }}$ graders $(\bar{X}=4.53, S=0.65)$ and $7^{\text {th }}$ graders $(\bar{X}=4.42, S=0.54)$ when compared to $8^{\text {th }}$ graders $(\bar{X}=4.24, S=0.69)$. In the Healthy Life and Nutrition dimension $[\mathrm{F}(3-904)=10,28$; $\mathrm{p}<.01]$, it is seen that there is a significant difference in favor of $5^{\text {th }}$ graders $(\bar{X}=4.28, S=0.70), 6^{\text {th }}$ graders $(\bar{X}=4.19, S=0.76)$ and $7^{\text {th }}$ graders $(\bar{X}=4.26, S=0.56)$ when compared to 8th graders $(\bar{X}=3.95, S=0.78)$. In the National Culture and Unity dimension $[\mathrm{F}(3-904)=28,29 ; \mathrm{p}<.01]$, it is seen that there is a significant difference in favor of $5^{\text {th }}$ graders $(\bar{X}=4.12, S=0.91)$, 6th graders $(\bar{X}=4.16, S=0.91)$ and $7^{\text {th }}$ graders $(\bar{X}=3.99, S=0.91)$ when compared to $8^{\text {th }}$ graders $(\bar{X}=3.46, S=1.08)$. In the awareness dimension $[F(3-904)=3.63 ; \mathrm{p}<0.05]$, it is seen that there is a significant difference in favor of $5^{\text {th }}$ graders $(\bar{X}=4.62, S=0.71)$ when compared to $8^{\text {th }}$ graders $(\bar{X}=4.44, S=0.78)$. In the respect dimension $[\mathrm{F}(3-904)=8.75 ; \mathrm{p}<0.01]$, it is seen that there is a significant difference in favor of $5^{\text {th }}$ graders $(\bar{X}=4.62, S=0.71)$ when compared to $8^{\text {th }}$ graders $(\bar{X}=4.44, S=0.78)$. On the averages of the total score of the scale $[F(3-904)=20.15 ; p<0.01)$, it is seen that there is a significant difference in favor of $5^{\text {th }}$ graders $(\bar{X}=4.35, S=0.50)$, 6th graders $(\bar{X}=4.31, S=0.55)$ and $7^{\text {th }}$ graders $(\bar{X}=4.25, S=0.46)$ when compared to $8^{\text {th }}$ graders $(\bar{X}=4.01, S=0.61)$.

The results of the ANOVA analysis made to compare the value levels related to the Physical Education course by the variable of number of siblings are given in Table 5 .

Table 5: Comparison of values levels by the variable of playing in the school team

\begin{tabular}{|c|c|c|c|c|c|c|c|}
\hline Dimension & School Team & $\mathrm{n}$ & $\overline{\mathrm{X}}$ & S & $\mathbf{t}$ & SD & p \\
\hline \multirow{2}{*}{$\begin{array}{l}\text { Sports } \\
\text { Culture }\end{array}$} & Yes & 138 & 4.29 & 0.490 & \multirow{2}{*}{5.40} & \multirow{2}{*}{0.906} & \multirow{2}{*}{0.000} \\
\hline & No & 770 & 3.97 & 0.660 & & & \\
\hline \multirow{2}{*}{ Solidarity } & Yes & 138 & 4.51 & 0.520 & \multirow{2}{*}{1.56} & \multirow{2}{*}{0.906} & \multirow{2}{*}{0.118} \\
\hline & $\mathrm{No}$ & 770 & 4.42 & 0.654 & & & \\
\hline \multirow{2}{*}{$\begin{array}{l}\text { Healthy Life } \\
\text { and Nutrition }\end{array}$} & Yes & 138 & 4.45 & 0.509 & \multirow{2}{*}{5.05} & \multirow{2}{*}{0.906} & \multirow{2}{*}{0.000} \\
\hline & $\mathrm{No}$ & 770 & 4.11 & 0.756 & & & \\
\hline \multirow{2}{*}{$\begin{array}{l}\text { National Culture } \\
\text { and Unity }\end{array}$} & Yes & 138 & 4.12 & 0.881 & \multirow{2}{*}{2.49} & \multirow{2}{*}{0.906} & \multirow{2}{*}{0.013} \\
\hline & No & 770 & 3.89 & 1.102 & & & \\
\hline \multirow{2}{*}{ Awareness } & Yes & 138 & 4.62 & 0.685 & \multirow{2}{*}{0.911} & \multirow{2}{*}{0.906} & \multirow{2}{*}{0.363} \\
\hline & No & 770 & 4.56 & 0.738 & & & \\
\hline \multirow{2}{*}{ Respect } & Yes & 138 & 4.62 & 0.559 & \multirow{2}{*}{2.29} & \multirow{2}{*}{0.906} & \multirow{2}{*}{0.022} \\
\hline & $\mathrm{No}$ & 770 & 4.46 & 0.747 & & & \\
\hline \multirow{2}{*}{ Average } & Yes & 138 & 4.41 & 0.428 & \multirow{2}{*}{4.31} & \multirow{2}{*}{0.906} & \multirow{2}{*}{0.000} \\
\hline & $\mathrm{No}$ & 770 & 4.19 & 0.572 & & & \\
\hline
\end{tabular}

As seen in Table 5, it was found that the results of the T-test for independent samples that was conducted to reveal whether there is a significant difference between the dimensions of the scale by the variable of playing in the school team of secondary school students participating in the study were statistically significant. In the sports culture dimension 
$[t(906)=5.40 ; p<0.01]$, it is seen that those playing in the school team $(\bar{X}=4.29, S=0.490)$ had more positive views than those who did not play in the school team ( $\bar{X}=3.97, N=0.660)$. In the healthy life and nutrition dimension $[t(906)=5.05 ; \mathrm{p}<0.01]$ it is seen that those playing in the school team $(\bar{X}=4.45, S=0.509)$ had more positive views than those who did not play in the school team $(\bar{X}=4.11, N=0.756)$. In the national culture and unity dimension $[t(906)=2.49 ; \mathrm{p}<0.05]$ it is seen that those playing in the school team $(\bar{X}=4.12, S=0.881)$ had more positive views than those who did not play in the school team ( $\bar{X}=3.89, N=1.102)$. In the respect dimension $[t(906)=2.29 ; \mathrm{p}<0.05]$, it is seen that those playing in the school team $(\bar{X}=4.62, S=0.559)$ had more positive views than those who did not play in the school team $(\bar{X}=4.46, N=0.747)$. According to the averages $[t(906)=4.31 ; p<0.01]$, it is seen that those playing in the school team $(\bar{X}=4.41, N=0.428)$ had more positive views than those who did not play in the school team $(\bar{X}=4.19, N=0.572)$. On the other hand, no statistically significant difference was found in the dimensions of solidarity [ $t(906)=1.56 ; p>0.05]$ and awareness [t(906) $=0,911 ; \mathrm{p}>0.05]$.

\section{Discussion, Conclusion and Recommendations}

In this part of the study, the results of the secondary school students' perceived values for physical education and the sports course that were obtained from the sub-dimensions of the research are presented.

According to the results of the study, it was found that the values levels of the students were high. Among the dimensions of the values scale, the awareness value had the highest average score, while the national culture and unity values had the lowest average score. The values levels of the students can be listed in descending order as; awareness, respect, solidarity, healthy life and nutrition, sports culture, and national culture and unity. The study conducted by Sağın and Karabulut (2019), similarly found that the values scores of secondary school students for physical education lessons were high. In the study conducted by Işıkgöz, Esentaş and Işıkgöz (2018), it was seen that students studying at secondary school exhibited the highest level of values for physical education and sports lesson in the "awareness" dimension and the lowest level value was "National Culture and Unity". Similarly, in the study conducted by Yücekaya (2017), the values scores of students studying at secondary school for the physical education course were found to be high.

In a comparison made by gender, when the values levels of the students were examined, it was found that there was a statistically significant difference in favor of female students. It is seen that there was a significant difference in all dimensions of the scale. In a study conducted by Çalışkur (2008) to investigate the relationship between life values and personality traits of university students, it was concluded that the average scores of "inner peace", "self-respect", "happiness", and "a comfortable life" were higher in female students than in male students. The results of the study conducted by Işıkgöz, Esentaş and Işıkgöz (2018) to examine the values levels of secondary school students for the Physical Education and Sports Course by various variables, showed that the values 
levels of the students differed significantly in the sub-dimensions of awareness, national culture and unity, healthy life and nutrition by gender; that there was a significant difference in favor of female students in the sub-dimensions of awareness and national culture and unity compared to male students; while the values level of male students were higher in the sub-dimension of healthy life and nutrition than those of the female students. Altınkök and Kurnaz (2018), in the study they conducted to examine the values of secondary school students for the physical education course, found that the value levels of students differed significantly by gender in favor of female students compared to male students. Thus, the results of the previous studies support the current study.

It was observed that the values levels of secondary school students differed significantly in all dimensions of the scale by the grade variable, and it was concluded as a result of the comparison between the groups that there was a significant difference in favor of lower grades in all groups. It has been concluded that as students' grade levels increase, their values levels towards physical education and the sports course decrease. This decrease may be due to the university entrance and similar exams, future concerns, a change in interests, or adolescence, which creates change as they grow.

It was concluded that the values levels of secondary school students differed significantly in the dimensions of sports culture, healthy life and nutrition, national culture and unity, and respect, and in terms of the scale total score in favor of those who played in the school team. The results of the studies conducted by Yücekaya (2017), Işıkgoz, Esentaş and Işıkgöz (2018), Altınkök and Kurnaz (2018) and Hünük (2006) are similar to those of this study and support this research.

The following recommendations have been made in the context of the findings and results of this study:

- Although their perceptions of value are generally high, students should be encouraged to participate in national day activities and to include every student to increase their perceptions of national culture and unity, which are at a lower level than other dimensions.

- Many studies have also found that female students' values perception is higher than that of male students in terms of the gender variable. The reasons for this can be examined in-depth with qualitative research methods.

- It is generally observed that as grade level increases, the values level of students for physical education and the sports course decreases. To prevent this decrease, students can be provided with training for effectively managing adolescence, university exams, and concerns for the future.

\section{Acknowledgments}

All authors also contributed to the whole work. We wish to express our gratitude to the participants who volunteered for this study. This research does not involve any funding, IRB approval and acknowledgment. 


\section{Conflict of Interest Statement}

The authors declare that they have no conflict of interest related to the study or preparation of the manuscript.

\section{About the Authors}

Mert Kurnaz is Master student in the Physical Education and Sport Education Field at Akdeniz University, Institute of Educational Sciences, Antalya, Turkey.

Dr. Mustafa Altinkök is Associate Professor Doctor at Akdeniz University, Faculty of Sports Sciences, Antalya, Turkey.

Dr. Serdar Özçetin is Assistant Professor Doctor at Akdeniz University, Faculty of Sports Sciences, Antalya, Turkey.

\section{References}

Akbaba Altun, S. (2003). Eğitim yönetimi ve değerler. Değgerler Ĕ̆itimi Dergisi,1(1), 7-18. Al-Serhan, K. A. (2015). The degree of adherence to educational values by the students of the university of Jordan in their point of view. International Education Studies, 9(1), 55.

Altınkök, M. \& Kurnaz, M. (2018). Spor bilimleri alanında yenilikçi yaklaşımlar. Ankara: Gece Akademi.

Aydın, M. Z. \& Akyol, Ş. (2012). Okulda değerler eğitimi. Ankara: Nobel Yayınları.

Bilgin, N. (1995). Sosyal psikolojide yöntem ve pratik çalışmalar. İstanbul: Sistem Yayıncılık.

Bulut, S. S. (2012). Gazi eğitim fakültesi öğrencilerinin değer yönelimleri. Uluslararası Türkçe Edebiyat Kültür Ĕ̆itim Dergisi, 1(3), 216-38.

Büyüköztürk, S., Çakmak, E. K., Akgün, O. E., Karadenız, Ş. ve Demirel, F. (2010). Bilimsel araştırma yöntemleri. Ankara: Pegem Akademi.

Çalışkur, A. Y. (2008). Üniversite öğrencilerinin yaşam değgerleri ile kişilik özellikleri arasındaki ilişki. Eğitim Bilimleri Enstitüsü, Rehberlik ve Psikolojik Danışmanlık Ana Bilim Dalı. Yayınlanmamış Doktora Tezi, İstanbul.

Dunn, J. S., Kinney, D. A. \& Hofferth, S. L. (2003). Parental ideologies and children's afterschool activities. American behavioral scientist, 46(10), 1359-1386.

Hünük, D. (2006). Ankara ili merkez ilçelerindeki ilköğretim ikinci kademe öğrencilerinin beden eğitimi dersine ilişkin tutumlarmın sını düzeyi, öğrenci cinsiyeti, öğretmen cinsiyeti ve spora aktif katılımları açısından karşılaştırılması. Yayınlanmamış Yüksek Lisans Tezi, Hacettepe Üniversitesi, Sağlık Bilimleri Enstitüsü, Ankara.

Işıkgöz, M. E., Esentaş, M. \& Işıkgöz, M. (2018). Ortaokul öğrencilerinin Beden Eğitimi ve Spor Dersine yönelik değer düzeylerinin çeşitli değişkenler açısından incelenmesi: Batman il örneği. International Journal of Social Sciences and Education Research, 4(4), 661-676.

Karasar, N. (2005). Bilimsel araştırma yöntemi (15. baskı) Ankara: Nobel Yayıncılık. Makroum, A. W. (2004). Values and civil responsibilities. Mansoura University. 
MEB (2018). Beden eğitimi ve spor dersi öğretim programı (Ortaokul 5, 6, 7 ve 8. Sınıflar). Ankara.

Milli Egitim Temel Kanunu, 1739. R. Gazete: 4/6/1973, Sayı: 14574

Perry, R. B. (1988). The horizons of value a critical study of human civilization.

Sağın, A. E. \& Karabulut, Ö. (2019). Beden Eğitimi ve Spor Dersine Yönelik Ortaokul Öğrencilerinin Değer Düzeylerinin İncelenmesi (Bağcılar İlçesi Örneği), International journal of mountaineering and climbing, 2(2), 27-34.

Yaşar A. (2017). Imam Hatip Ortaokulu Öğrencilerinin Beden Ĕğitimi ve Spor Dersine Katılımına Yönelik Ana Baba Tutumlarının Farklı Değişkenler Açısından İncelenmesi, Yayımlanmamış Yüksek Lisans Tezi, Atatürk Üniversitesi Eğitim Bilimleri Enstitüsü, Beden Eğitimi ve Spor Öğretmenliği Ana Bilim Dalı. Erzurum.

Yücekaya, M. A. (2017). Ortaokul öğrencilerinin beden eğitimi ve spor dersine ilişkin değerlerinin incelenmesi, Yayımlanmamış Yüksek Lisans Tezi, İnönü Üniversitesi, Sağlık Bilimleri Enstitüsü, Beden Eğitimi ve Spor Anabilim Dalı. Malatya. 
Creative Commons licensing terms

Author(s) will retain the copyright of their published articles agreeing that a Creative Commons Attribution 4.0 International License (CC BY 4.0) terms will be applied to their work. Under the terms of this license, no permission is required from the author(s) or publisher for members of the community to copy, distribute, transmit or adapt the article content, providing a proper, prominent and unambiguous attribution to the authors in a manner that makes clear that the materials are being reused under permission of a Creative Commons License. Views, opinions and conclusions expressed in this research article are views, opinions and conclusions of the author(s). Open Access Publishing Group and European Journal of Education Studies shall not be responsible or answerable for any loss, damage or liability caused in relation to/arising out of conflicts of interest, copyright violations and inappropriate or inaccurate use of any kind content related or integrated into the research work. All the published works are meeting the Open Access Publishing requirements and can be freely accessed, shared, modified, distributed and used in educational, commercial and non-commercial purposes under a Creative Commons Attribution 4.0 International License (CC BY 4.0). 